\title{
Kontroll og tilsyn med medisinsk forskning
}

\author{
Sigmund Simonsen og Magne Nylenna \\ Nylennautvalget, Sosial- og helsedirektoratet, Pb. 8034 Dep, 0031 Oslo \\ telefon 24163000 e-post: sigmund.simonsen@shdir.no og magne.nylenna@shdir.no Hjemmeside: www.forskningsregulering.dep.no
}

\begin{abstract}
SAMMENDRAG
En rekke ulike organer fører i dag kontroll med medisinsk forskning i Norge. Det er imidlertid vanskelig, både for forskere og myndigheter, å ha full oversikt over hvilke skjemaer som skal sendes hvor, og hvilken instans som har ansvaret for hva. Organenes virksomhet overlapper til en viss grad hverandre og de er satt til å håndheve et fragmentert og uklart regelverk. Disse forhold kan være et problem, både for forsøkspersoner og forskere, men også for samfunnet for øvrig. Artikkelforfatterne er tilknyttet Nylennautvalget, som er oppnevnt av Regjeringen for å gjennomgå reguleringen av medisinsk forskning som involverer mennesker og humant biologisk materiale. Utvalget skal komme med forslag til tiltak som kan sikre en hensiktsmessig og klar regulering av medisinsk forskning.
\end{abstract}

\section{Simonsen S, Nylenna M. Control and supervision of medical research. Nor J Epidemiol 2004; 14 (1):}

$$
5-12 \text {. }
$$

\section{ENGLISH SUMMARY}

A great many agencies monitor medical research in Norway. Both researchers and public authorities find it hard to get an overview over the current system. The agencies' scopes are overlapping and they apply a fragmentary and unclear set of rules. Those circumstances may be a problem for research subjects and researchers, as well as for the society at large. The authors are engaged in the Nylennautvalget, a Committee of independent national experts appointed by the Norwegian government to evaluate the regulation of medical research involving human subjects and human material. The Committee is asked to recommend initiatives that may secure a clear and adequate regulation of medical research.

\section{INNLEDNING}

Medisinsk forskningsvirksomhet er i dag underlagt en rekke reguleringer. Med regulering sikter vi til alle regler og handlingsnormer som på en eller annen måte påvirker og styrer gjennomføringen av medisinsk forskning.

Medisinsk forskning er i dag ikke særskilt regulert i en egen lov som har sitt primære formål å fremme god forskning. Med god forskning menes etisk og faglig forsvarlig forskning av høy metodologisk kvalitet, som gir ny viten. Tvert i mot har vi identifisert over 40 lover, forskrifter, konvensjoner, deklarasjoner, veiledninger og lignende, som mer eller mindre direkte regulerer medisinsk forskning (1). Disse reguleringene er utarbeidet av så vel offentlige myndigheter som den medisinske profesjonen selv og er av både nasjonal og internasjonal opprinnelse.

Reguleringer på dette området faller i to prinsipielt forskjellige kategorier, som igjen har flere underkategorier: Den ene hovedkategorien reguleringer er rettsregler (lover) skapt og håndhevet av organer samfunnet har utpekt til dette formål. Den andre hovedkategorien reguleringer er profesjonsnormer som i utgangspunktet skapes og håndheves av profesjonen selv.
Mens profesjonsnormer kan sees på som normativ etikk (akseptert atferd) utviklet av den aktuelle profesjon, fremstår rettsregler som normativ etikk utviklet av samfunnet. Forholdet mellom jus og etikk kan beskrives ved at rettsregler opphøyer (rettsliggjør) visse normative oppfatninger som samfunnets offisielle og autorative syn på hva som er rett og galt, lovlig og ulovlig, etisk og uetisk, akseptabel og ikke-akseptabel handlemåte. Rettsreglenes viktigste funksjon kan sies å være styring av individuell og kollektiv atferd for å oppnå samfunnsmessige mål, som for eksempel god og forsvarlig forskning (2).

Det eksisterende mangfold av reguleringer bidrar imidlertid til at regelverket fremstår som fragmentert og kan oppleves som uoversiktlig og utilgjengelig. Det kan skape usikkerhet omkring hva som er etisk, akseptert og lovlig atferd. Forskere er likefullt ansvarlige for å utøve sin virksomhet i tråd med gjeldende reguleringer.

Vedtakelse av atferdsnormer i form av lover og regler er imidlertid ikke i seg selv ansett som tilstrekkelig for å sikre at forskere og andre faktisk opptrer i overensstemmelse med gjeldende reguleringer (aksepterte handlingsnormer). Reguleringene følges derfor opp gjennom etablering av organer som har til oppga- 
ve å føre kontroll og tilsyn. På den måten skal regelbrudd forhindres og god forskning fremmes. Det at forskere vet at de vil kunne bli kontrollert og stilt til ansvar dersom de ikke opptrer innenfor gjeldende normer og regler, antas å ha en preventiv effekt.

\section{Forholdet mellom atferdsregler, organisatoriske regler og saksbehandlingsregler}

Også kontroll- og tilsynssystemet er etablert i medhold av reguleringer. Det kan skilles mellom atferdsregler, organisatoriske regler og saksbehandlingsregler. At forskningen skal utføres av kvalifisert personell og baseres på forsøkspersoners frivillige og informerte samtykke, samt ulike forbud og påbud, er eksempler på atferdsregler, ved at de regulerer hvordan forskere kan handle eller ikke kan handle. Oppnevnelse av kontroll- og tilsynsorganer er eksempler på organisatoriske regler. Regler som skal sikre at organenes virksomhet utøves forsvarlig, er eksempler på saksbehandlingsregler.

Det er imidlertid ingen eksakt grense mellom disse. Tvert i mot er det viktig å se sammenhengen mellom atferdsregler og organisatoriske regler og saksbehandlingsregler (3). Dersom atferdsreglene er kompliserte, uoversiktlige, ikke harmonisert og/eller uklare, stiller det store krav til saksbehandlingen. Klare rammer (enhetlig og klart regelverk) er ofte en forutsetning for god kontroll, ved at det motvirker vilkårlighet og sikrer forutsigbarhet. Det bidrar også til at prosessen ikke blir for skjønnsmessig (dvs. ren synsing), noe som forenkler kontrollørenes arbeid og reduserer deres ansvar. På den annen side er det umulig å detaljregulere ethvert spørsmål på et så komplisert område som dette. Det må utøves noe skjønn. Detaljregulering er heller ikke ønskelig, fordi regelverket bør være fleksibelt på et område der utviklingen går raskt og virksomheten er uensartet. Hvordan kontrollvirksomheten er organisert, har betydning i flere retninger. Dersom både tolkningen av regelverk og faktavurderinger er kompliserte, kan det være nødvendig å fordele ulike kontrolloppgaver på flere spesialiserte organer.

\section{Et historisk tilbakeblikk}

Før det fantes særskilte reguleringer av medisinsk forskning utledet domstoler retten fra mer generelle rettslige prinsipper. Mest nærliggende var da den alminnelige strafferetten og den alminnelige erstatningsretten. Saken mot Gerhard Henrik Armauer Hanssen (1841-1912) var banebrytende både i et nasjonalt og internasjonalt perspektiv. Armauer Hanssen ble i 1880 stilt for retten og fradømt sin stilling som lege ved Pleiestiftelsen for Spedalske No 1 i Bergen, fordi han hadde utført eksperiment med poding av leprøst materiale på en pasient uten pasientens samtykke (4). Med utgangspunkt $\mathrm{i}$ den alminnelige strafferetten utledet således domstolen et krav om samtykke (5). Et annet velkjent eksempel er Nürnbergprosessen, hvor Militær Domstol I i saken USA v. Karl Brandt et al. dømte 23 tyske leger for krigsforbrytelser og forbrytelser mot menneskeheten 19. august 1947 (6). Med utgangspunkt $\mathrm{i}$ internasjonale strafferettslige prinsipper utledet domstolen ti prinsipper for medisinsk forskning, den såkalte Nürnbergkodeksen. I 1945 ble de Forente Nasjoner (FN) etablert og i 1948 vedtok FN's generalforsamling Verdenserklæring om menneskerettigheter, hvor grunnleggende etiske prinsipper og idealer for forholdet mellom stat og borger ble formulert. Verdenserklæringen var startskuddet for en utvikling av menneskerettigheter som kom til å få stor betydning på svært mange områder, også for medisinsk forskning (7). Menneskerettighetene bygger på naturrettslig tankegang og oppstiller et vern av bl.a. enkeltmenneskers integritet, frihet og autonomi. Verdenserklæringen ledet til vedtakelse av en rekke rettslig forpliktende konvensjoner. I 1999 ble fire av disse gjort gjeldende som norsk lov, med forrang foran andre lover, ved vedtakelsen av menneskerettighetsloven. En direkte link til Nürnbergkodeksen finnes i FN-konvensjonen om sivile og politiske rettigheter av 1966 hvor det $i$ artikkel 7 heter at ingen må uten sitt frie samtykke, utsettes for medisinske eller vitenskapelige eksperimenter. Parallelt med dette videreutviklet Verdens legeforening Nürnbergkodeksen da de vedtok Helsinkideklarasjonen i 1964 (8). Vedtakelsen av Helsinkideklarasjonen forhindret imidlertid ikke uetisk forskning, og i 1975 vedtok Verdens legeforening en tilføyelse hvor etikkomiteer anbefales opprettet. Helsinkideklarasjonen er bredt anerkjent, også utenfor den medisinske profesjon, bl.a. av norske myndigheter. I tillegg har vi i Norge i løpet av de siste årene fått en rekke nye lover og organer som regulerer og fører kontroll med medisinsk forskning.

Ved Europarådets konvensjon om menneskerettigheter og biomedisin av 1997 (9), forenes Helsinkideklarasjonens forskningsetikk med alminnelige menneskerettigheter. Når Norge ratifiserer konvensjonen, er vi folkerettslig forpliktet til å gjennomføre konvensjonen i norsk rett. Konvensjonen forutsetter kontroll og tilsyn med forskningen i form av etikkomiteer. Den Europeiske Unions direktiv på legemiddelområdet stiller også store krav til nasjonal kontroll- og tilsyn (10). Direktivet gjennomføres i norsk rett ved den nye legemiddelforskriften som trådte i kraft 1. mai 2004 (11).

\section{Ulike former for kontroll og tilsyn}

Det kan være hensiktsmessig å skille mellom tre hovedformer for kontroll og tilsyn med forskning: •

- Forhåndskontroll (før prosjektet settes i gang).

- Løpende kontroll eller tilsyn (mens prosjektet gjennomføres).

- Etterhåndskontroll (etter at prosjektet er avsluttet).

Gjeldende kontroll- og tilsynssystem i Norge er hovedsakelig konsentrert omkring forhåndskontroll. Det innebærer at de fleste medisinske forskningsprosjekter som involverer mennesker, må ha blitt tilrådd, godkjent, fått konsesjon eller lignende før de kan settes $\mathrm{i}$ 
gang. Selv om idealet er forskningsfrihet, er det lagt til grunn at det av hensyn til forsøkspersoner og samfunnet for øvrig er nødvendig å kontrollere at medisinske forsøk er planlagt utført i overensstemmelse med gjeldende lover og regler. Man vil med andre ord sikre at prosjektene er faglig og etisk forsvarlige. Selv om prosjektet er godt planlagt, er det imidlertid ikke sikkert at selve utøvelsen forløper som planlagt. Enkelte organer fører av den grunn løpende kontroll eller tilsyn på visse områder. Det er først og fremst denne kontrollformen begrepet "tilsyn" henspeiler til. Til tross for den omfattende forhåndskontrollen føres det $\mathrm{i}$ dag ingen oversikt over avsluttende prosjekter. Man vet derfor ikke hvordan det går med alle de prosjektene som er tilrådd eller godkjent. Legemiddelforskriften representerer her et unntak, ved at § 5-9 etablerer en form for etterhåndskontroll ved klinisk utprøving av legemidler (se nedenfor). Etterhåndskontroll kan også skje dersom det i ettertid klages over forsøket, for eksempel fra forsøkspersoner som mener de har lidd overlast.

\section{Ulike typer kontroll- og tilsynsorganer}

Kontroll- og tilsynsorganene kan deles inn i tre hovedkategorier:

- Offentlige myndighetsorganer, for eksempel Helsedepartementet og Datatilsynet. Dette er organer som med hjemmel i lov blant annet driver med offentlig myndighetsutøvelse, herunder kontroll og/eller tilsyn med de deler av medisinsk forskningsvirksomhet som faller innenfor deres myndighetsområde. Av disse kan det skilles mellom lovgivende makt (Stortinget), den dømmende makt (domstolene) og den utøvende makt (Regjeringen og forvaltningen). Alle offentlige forvaltningsorganer er underlagt forvaltningsloven som stiller opp en del sentrale saksbehandlingsregler som skal ivareta borgerens rettssikkerhet i møte med det offentlige (12). Det er her tale om grunnleggende regler om god forvaltningsskikk, habilitet, taushetsplikt, begrunnelse av vedtak og klageadgang. Dessuten er alle forvaltningsorganer pålagt å gi råd gjennom den alminnelige veiledningsplikten. Offentlighetsloven skal sikre offentligheten innsyn i forvaltningens virksomhet. Innsynsretten gjør det mulig å føre kontroll med kontrollørene. Domstolene er underlagt tilsvarende prosessuelle regler.

- Myndighetsncere organer, for eksempel de regionale komiteer for medisinsk forskningsetikk (REK). Denne særegne kategorien innbefatter organer som formelt sett ikke driver myndighetsutøvelse, men som på grunn av sin karakter og kontrollfunksjon ligger så nær slik virksomhet at det er naturlig å sammenligne dem med offentlige myndighetsorganer.

- Frie aktører, for eksempel Norsk Samfunnsvitenskapelig Datatjeneste AS (NSD), institusjonsbaserte forskningsutvalg og lignende. Det er her tale om en uensartet gruppe organer, gjerne opprettet av private aktører som ikke har som primærformål å drive med myndighetsutøvelse, men heller kvalitetssikre forskning som de selv på ulike måter er involvert $\mathrm{i}$.

\section{ULIKE KONTROLL- OG TILSYNSORGANER}

De mest sentrale kontroll- og tilsynsorganer for medisinsk forskning er fremstilt i figur 1 .

\section{Statsforvaltningen - sarlig om Helsedepartementet}

Etter Grunnloven tilligger det Regjeringen å organisere departementer og den øvrige statsforvaltning slik den til enhver tid finner hensiktsmessig. Helsedepartementet er overordnet offentlig forvaltningsmyndighet på helseområdet (13). Helsedepartementet har imidlertid delegert de fleste kontroll- og tilsynsoppgaver på dette området til underliggende etater. Disse etatene er $\mathrm{i}$ varierende grad uavhengige av departementet. Det innebærer blant annet at departementet normalt ikke kan instruere disse etatene når de avgjør enkeltsaker.

Helsedepartementet har til tross for omfattende delegeringer fremdeles enkelte kontrolloppgaver. Ved samling av humant biologisk materiale og opplysninger avledet av dette, som anvendes til forskning, skal det $\mathrm{i}$ følge biobankloven opprettes en forskningsbiobank. Etter at en etikkomité forst har behandlet prosjektet, skal melding om opprettelse av forskningsbiobank sendes Helsedepartementet. Helsedepartementet kan nekte opprettelse selv om etikkomiteen har tilrådd prosjektet dersom etiske hensyn eller tungtveiende samfunnsmessige interesser tilsier det.

\section{Sosial-og helsedirektoratet}

Sosial- og helsedirektoratet (Direktoratet) er et statlig forvaltningsorgan underlagt Helsedepartementet som skal bidra til å gjennomføre og iverksette nasjonal politikk i helse- og sosialsektoren. Direktoratet ble etablert 1. januar 2002 etter en sammenslåing av en rekke offentlige organer. Direktoratet har fått delegert mange forvaltningsoppgaver knyttet til medisinsk forskning fra Helsedepartementet. Blant annet har Direktoratet overtatt samtlige forvaltningsoppgaver etter bioteknologiloven. Direktoratet forvalter også de delene av genteknologiloven som omhandler innesluttet bruk av genmodifiserte organismer. Videre forvalter Direktoratet biobankloven i forhold til overføring av biobankmateriale til utlandet ( $§ 10)$, endret, utvidet, eller ny bruk $(\S 13)$ og andres tilgang til materiale i en biobank (§ 15). Direktoratet godkjenner også prosjekter som omhandler bruk av fostervev m.m. etter transplantasjonsloven. Dessuten behandler Direktoratet søknader om fritak fra taushetsplikt i forskningsøyemed etter forvaltningsloven $\S 13 \mathrm{~d}$ og helsepersonellloven $\S 29$ første ledd (14). 
Figur 1. Oversikt over de mest sentrale kontroll- og tilsynsorganer for medisinsk forskning og deres arbeidsområde og rolle. Organer i stiplet ramme driver ikke med kontroll og tilsyn som sådan, men er en del av systemet i videste forstand.

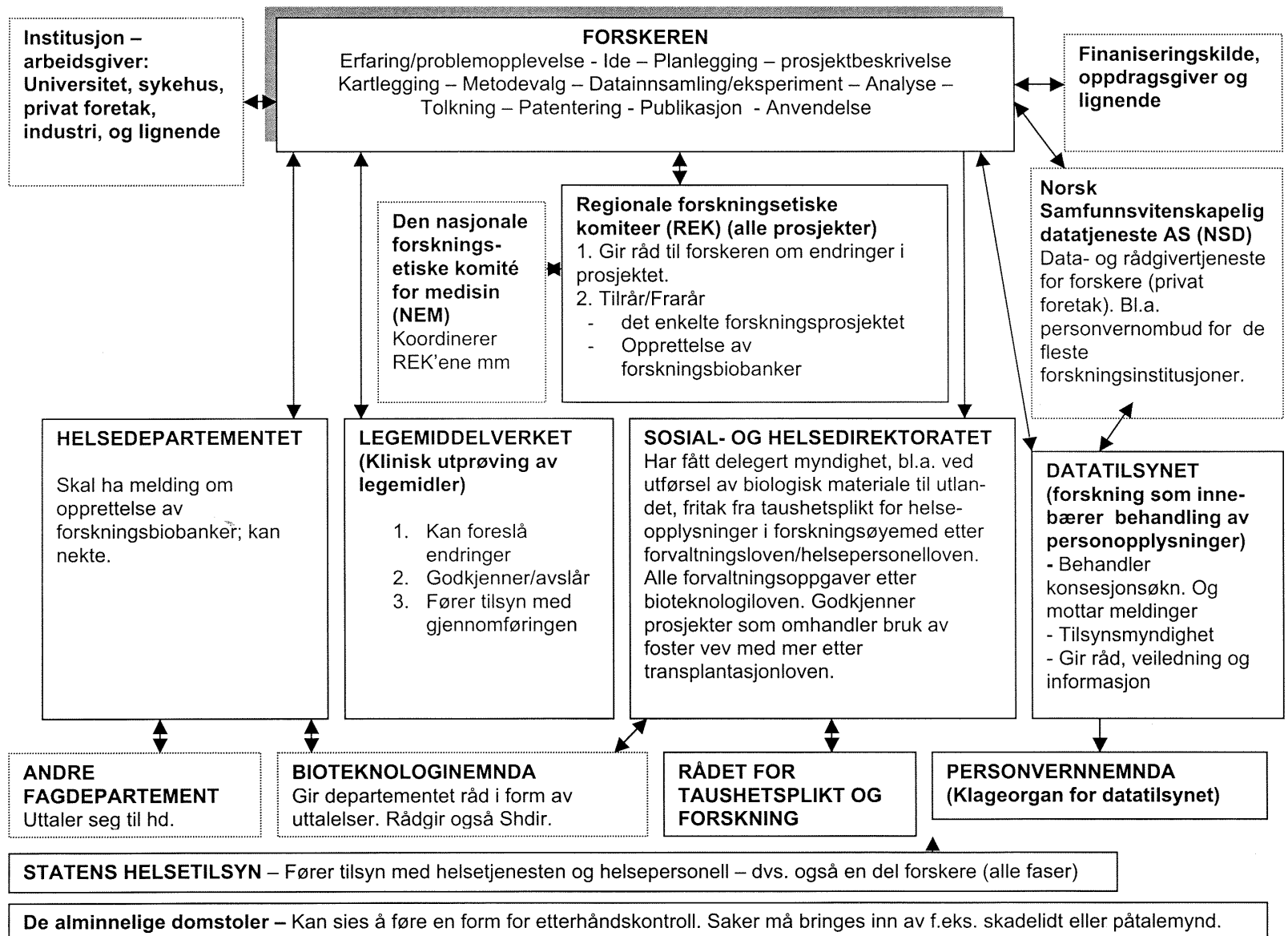

\section{Rådet for taushetsplikt og forskning}

Dersom en søknad om fritak for taushetsplikten ikke er kurant, skal Sosial- og helsedirektoratet forelegge søknaden for Rådet for taushetsplikt og forskning, jf. forskrift til forvaltningsloven $\S 13 \mathrm{~d}$. Rådet er et uavhengig forvaltningsorgan underlagt Justisdepartementet og har fire medlemmer. Rådet kan samtykke til at Direktoratet gjør fritak for taushetsplikten i forskningsøyemed (15).

\section{Bioteknologinemnda}

I prinsipielle saker etter bioteknologiloven og genteknologiloven kan Helsedepartementet eller Sosialog helsedirektoratet innhente uttalelser fra Bioteknologinemnda. Bioteknologinemnda er et frittstående rådgivende organ for forvaltningen, som særlig vurderer og drøfter prinsipielle eller generelle spørsmål knyttet til bioteknologi og genteknologi (16). Bioteknologinemnda driver verken med kontroll eller tilsyn, men omtales likevel her da den er en del av "systemet".

\section{Statens legemiddelverk}

Statens legemiddelverk ble etablert i 1974 som statens legemiddelkontroll, og er et uavhengig forvaltningsorgan underlagt Helsedepartementet. Legemiddelverket har som sin fremste oppgave å godkjenne legemidler som industrien vil selge i Norge (17). Legemiddelverket fører imidlertid også forhåndskontroll, løpende tilsyn og etterhåndskontroll med klinisk $u t$ prøving av legemidler, dvs. legemiddelforskning.

Legemiddelverket skal blant annet ha melding om enhver klinisk utprøving av legemidler etter at et slikt forsøk er vurdert av etikkomiteene. Legemiddelverkets vurdering av meldinger om utprøving av legemidler skjer på bakgrunn av legemiddelforskriften samt Helsinkideklarasjonen og europeiske retningslinjer for Good Clinical Practice (GCP). I tråd med den alminnelige veiledningsplikten legger Legemiddelverket vekt på å ha en god dialog med forskere for å komme frem til gode løsninger. Videre foretar Legemiddelverket som et ledd i sin tilsynsvirksomhet, inspeksjoner og lignende for å overvåke gjennomføringen av forsøk. Endelig skal Legemiddelverket (og etikkomi- 
teene) i henhold til legemiddelforskriften $\S 5-9$ ha årsrapport for utprøvinger over lang tid, samt sluttrapport etter at studien er avsluttet.

\section{Statens helsetilsyn}

Statens helsetilsyn er et uavhengig forvaltningsorgan underlagt Helsedepartementet. Fylkeslegene opptrer som "Helsetilsynet i fylkene", og hører som sådan direkte under Helsetilsynet.

Statens helsetilsyn har røtter tilbake til 1809, da Det norske sundhedskollegiet ble opprettet. Det tidligere Helsedirektoratet ble omorganisert og endret til Statens helsetilsyn i 1992. Ved omorganiseringen 1. januar 2002, ble tilsynsprofilen styrket, mens statlige handlingsplaner og mange forvaltningsoppgaver m.m. ble overført til det nye Sosial- og helsedirektoratet (18).

Helsetilsynet fører i henhold til tilsynsloven tilsyn med helsetjenesten i hele landet. Denne tilsynsvirksomheten innbefatter bl.a. behandling av klager på helsepersonell og virksomheter og en vurdering av reaksjoner overfor disse. Hva som omfattes av begrepene "helsetjenesten", "helsevesen" og "helsepersonell" kan i enkelte grensetilfelle være noe uklar. Mange som utfører medisinsk forskning er for eksempel helsepersonell, men ikke alle. En del forskning omfattes i tillegg av helsepersonellovens begrep "helsehjelp", for eksempel terapeutisk forskning, men neppe ikketerapeutisk forskning. Tolkningen av disse begrepene er dermed sentral. Helsetilsynet tolker begrepene, og dermed sitt virksomhetsområde, relativt vidt, og fører $\mathrm{i}$ praksis et visst tilsyn med gjennomføringen av en del, men neppe all, medisinsk forskning.

\section{Datatilsynet}

Datatilsynet er et uavhengig forvaltningsorgan underlagt Arbeids- og administrasjonsdepartementet. Datatilsynet ble etablert i 1980 og har til oppgave å beskytte den enkelte mot at personverninteressene krenkes gjennom behandling av personopplysninger.

Datatilsynets virksomhet er regulert i personopplysningsloven og helseregisterloven. De fører både forhåndskontroll og løpende tilsyn (19).

Dersom et forsøk innebærer registrering og bruk av personopplysninger må melding sendes Datatilsynet. Dersom personopplysningene er sensitive, noe helseopplysninger regelmessig er, må forskeren ha konsesjon fra Datatilsynet. Konsesjon er en form for forhåndstillatelse.

\section{Personvernnemnda}

Personvernnemnda er et uavhengig forvaltningsorgan bestående av 7 medlemmer, som behandler klager på vedtak som Datatilsynet fatter. Nemnda er opprettet med hjemmel i peronsopplysningsloven $\S 43$ og underlagt Arbeids- og administrasjonsdepartementet (20).

\section{Domstolene}

Domstolene skiller seg klart fra de nevnte forvaltningsorganer ved at de hører inn under den dømmende makt og ikke er en del av den utøvende makt (statsforvaltningen). Domstolene har som en av sine viktigste funksjoner å avgjøre rettstvister mellom borgerne og mellom borgerne og offentlige myndigheter. Domstolene anvender den retten som er skapt av lovgiver (Stortinget). De avgjør de enkelttilfellene de får seg forelagt på grunnlag av gjeldende rett. Lov og andre rettskilder gir ikke alltid noe sikkert svar på de rettsspørsmål som oppstår, og da må domstolene selv finne fram til løsningen - utøve et såkalt rettslig skjønn. Ved avgjørelsen av et tvilsomt rettsspørsmål vil hensynet til hva som er rettferdig, (etisk) forsvarlig og hensiktsmessig ofte spille en vesentlig rolle (21).

Borgere som mener at de har lidd urett kan anlegge sak for domstolene. For eksempel kan skadelidte forsøkspersoner anlegge erstatningssak mot ansvarlig forsker. Dermed fører domstolene såkalt domstolskontroll med forskere. Dersom forskere ikke er enig $i$ nevnte forvaltningsorganers rettsanvendelse kan forskere bringe saken inn for domstolene. Dermed fører domstolene også kontroll med forvaltningen.

I Norge har imidlertid ikke domstolene spilt noen sentral rolle som kontrollorganer for medisinsk forskning, slik domstolene har gjort det i noen andre land, særlig USA. Norske domstoler har heller ikke vært sentrale ved utviklingen av gjeldende rett på dette området, slik de for eksempel har vært det innenfor erstatningsretten. Det at svært få saker vedrørende medisinsk forskning blir brakt inn for domstolene, kan ha sammenheng med at det sjelden oppstår skader ved forskning eller at det ellers ikke er behov for å få overprøvd omtalte forvaltningsorganers avgjørelser. Det kan igjen tolkes som at forskning i Norge i hovedsak utøves forsvarlig og at forskerne innfinner seg med forvaltningsorganenes myndighetsutøvelse. Det siste kan være tilfelle ved at de fleste forvaltningsorganer ofte legger opp til en dialog med forskeren, jf. veiledningsplikten, slik at forsker og forvaltningsorgan finner frem til en løsning. Andre årsaker til at saker ikke bringes inn for domstolene, kan være at så vel forskere som forsøkspersoner kvier seg for å bringe en sak inn for domstolene.

\section{Myndighetsnare organer - De regionale komiteer for medisinsk forskningsetikk (REK), og Den nasjo- nale komité for medisinsk forskningsetikk (NEM)}

Etikkomiteer som nevnt i Helsinkideklarasjonen, ble først permanent etablert i Norge av det nåværende Utdannings- og forskningsdepartementet i 1985. Det skjedde etter press fra leger som hadde problemer med å få publisert sine resultater i utlandet uten først å ha fått forhåndsvurdert forskningsprosjektene. Opprettelsen var dermed ikke en reaksjon på en bekymring for uforsvarlig forskning i Norge (22). De regionale komiteer for medisinsk forskningsetikk (REK) er ikke 
hjemlet i lov, og deres formelle stilling er noe uklar. Deres rolle er derfor nå til vurdering både i Utdannings- og forskningsdepartementet og i Nylennautvalget. Etikkomiteer er til sammenligning lovhjemlet både i Sverige og Danmark. I 1995 ble Den nasjonale komité for medisinsk forskningsetikk (NEM) etablert som et rådgivnings- og koordineringsorgan for de fem regionale komiteene (23).

Det finnes fem regionale komiteer, en i hver helseregion. Hver komité har åtte medlemmer med ulik bakgrunn. Komiteene har i praksis en meget sentral (forhånds-) kontrollfunksjon, ved at stort sett alle biomedisinske forskningsprosjekter hvor det inngår forsøk på mennesker, i henhold til komiteenes mandat, skal forelegges en komité $f ø r$ de igangsettes. Det gjelder både terapeutisk og ikke-terapeutisk forskning. I følge mandatet omfattes også forskning på identifiserbart eller anonymt humant biologisk materiale og identifiserbare eller anonyme data.

Komiteene tilrår eller frarår forskningsprosjektet. Vanligvis skjer dette etter en dialog med forskeren. Komiteenes "råd" er ikke rettslig bindende. Det er således $\mathrm{i}$ prinsippet opp til forskeren om han/hun vil følge komiteens råd. Men i praksis gjøres dette så godt som alltid, da det er en del indirekte konsekvenser av å unnlate å følge rådet. For eksempel forutsetter i praksis Datatilsynet, Statens legemiddelverk og Helsedepartementet at komiteene har tilrådd prosjektet. I tillegg vil man neppe få publisert resultatet $\mathrm{i}$ et anerkjent tidsskrift $\mathrm{i}$ henhold til den såkalte Vancouverkonvensjonen som sentrale medisinske tidsskrifter verden over har sluttet seg til (24). Dermed fremstår komiteens tilrådning for alle praktiske formål, som en forhåndstillatelse. Komiteenes reelle myndighet er dermed stor og det er nærliggende å karakterisere dem som "myndighetsnære organer". Komiteene treffer imidlertid, i følge komiteenes mandat, ikke "enkeltvedtak". I forvaltningslovens $\S 2$ er enkeltvedtak definert som "en avgjørelse som treffes under utøving av offentlig myndighet og som generelt eller konkret er bestemmende for rettigheter eller plikter til private personer (enkeltpersoner eller andre private rettssubjekter)". Fordi mandatet bestemmer at komiteene ikke treffer enkeltvedtak, gjelder ikke forvaltningslovens regler om begrunnelse av vedtak og klage for komiteenes virksomhet. I 2001 ble imidlertid deler av forvaltningsloven og hele offentlighetsloven gjort gjeldende for komiteene. Selv om komiteenes formelle status er noe uklar, nyter de stor respekt både blant forskere og offentlige myndigheter.

Komiteene vurderer de fleste sider ved et forskningsprosjekt. Vurderingene er basert på "en alminnelig forskningsetisk vurdering, hvor det også tas hensyn til forskningsetiske retningslinjer av nasjonale og internasjonale organer", (Standard prosedyrer for saksbehandling i De regionale komiteer for medisinsk forskningsetikk). Dersom forsøket involverer utprøving av legemidler må komiteene i tillegg til sitt mandat og interne instrukser, utøve sin virksomhet $\mathrm{i}$ henhold til den nye legemiddelforskriften. Involverer forsøket innsamling og bruk av humant biologisk materiale skal biobankloven anvendes. Hvordan vurderingstemaet skal bestemmes hvor forsøket berøres av flere ikkeharmoniserte sett med lover og normer, sier komiteenes mandat ingen ting om.

\section{Uredelighetsutvalg}

Fra 1994 til 2001 eksisterte det et utvalg opprettet av Norsk forskningsråd, kalt Nasjonalt utvalg for vurdering av uredelighet i helsefaglig forskning. Utdannings- og forskningsdepartementet vurderer $\mathrm{i}$ disse dager hvorvidt et slikt utvalg skal gjenopprettes, om enn $\mathrm{i}$ endret form.

Frie aktorer - sarlig om personvernombud og Norsk Samfunnsvitenskapelig Datatjeneste AS (NSD)

I følge $\S 7-12$ i forskrift til personopplysningsloven kan Datatilsynet "samtykke $i$ at det gjøres unntak fra meldeplikt etter personopplysningsloven $\S 31$ første ledd, dersom den behandlingsansvarlige utpeker et uavhengig personvernombud som har i oppgave å sikre at den behandlingsansvarlige følger personopplysningsloven med forskrift." Hvem som helst kan i prinsippet utpekes som personvernombud. Ullevål sykehus har for eksempel eget personvernombud.

Universitetene, de statlige høyskolene, de vitenskapelige og private høyskolene, en rekke helseforetak og andre forskningsinstitusjoner har inngått en avtale med Norsk Samfunnsvitenskapelig Datatjeneste AS (NSD) om at NSD skal være personvernombud for dem (24). NSD er et aksjeselskap eid av Forskningsrådet og tilbyr også andre tjenester til forskere. Forskere tilknyttet de institusjoner som har utpekt NSD som personvernombud, skal melde fra til NSD i stedet for til Datatilsynet dersom vedkommende har meldeplikt etter personopplysningsloven eller helseregisterloven. NSD vurderer innkomne meldeskjema og videre saksgang avhenger om prosjektet er underlagt meldeplikt eller konsesjonsplikt. NSD oversender konsesjonspliktige prosjekter til Datatilsynet, som behandler meldingen på bakgrunn av NSD's innstilling. Meldepliktige prosjekter behandles kun av NSD.

Det finnes også andre "frie" aktører som i en eller annen form har en kontroll og/eller tilsynsfunksjon. Et eksempel kan være institusjonsbaserte forskningsutvalg. Slik intern- eller institusjonsbasert kontroll er imidlertid lite utbredt i Norge.

\section{DISKUSJON}

Figur 1 og den korte beskrivelsen av gjeldende kontroll- og tilsynssystem viser at det er et mangfoldig system. Antallet organer kan for enkelte forskere fortone seg høyt og systemet kan virke overveldende og uoversiktlig.

Organene skal gjennom sin kontrollvirksomhet gi råd og veiledning om et komplisert regelverk og sikre 
at forskere opptrer forsvarlig og i overensstemmelse med gjeldende lover og regler. På den måten kan organene medvirke til å forenkle og fremme god forskning. Samtidig forhindres dårlig forskning, noe som er i alles interesse.

Kontroll og tilsyn er imidlertid normalt tid- og ressurskrevende for alle parter - både for dem som blir kontrollert, og for de som kontrollerer. Unødvendig mange og/eller omfattende kontrollordninger vil dermed kunne hemme (den redelige) forskerens arbeide. For eksempel kan det sinke prosessen med å finne frem til en forbedret behandlingsmetode. I en undersøkelse hvor de etter en sammenstilling av amerikanske og britiske krav til informert samtykke for deltakere $\mathrm{i}$ ISIS-2 studien, anslo at omkring 10000 unødvendige dødsfall hadde som sin direkte årsak det som av en eller annen grunn sinket rekrutteringen til forsøket i USA (26). I en kommentar til denne undersøkelsen hevdes det på lederplass i British Medical Journal at de byrder en etisk gjennomgang medfører, bare kan rettferdiggjøres dersom det kan dokumenteres at en slik gjennomgang fremmer mer enn den hemmer pasientenes interesser (27). På den annen side er det en fremmed tankegang i norsk (og trolig også andre lands) rettstradisjon å foreta en kostnad-nytte analyse med forsøkspersoners rettssikkerhet overfor kroppslige og andre inngrep på den ene siden og nytten av ny helseviten på den andre siden.

Det forhold at flere instanser har myndighet til å vurdere mange av de samme sidene ved samme forskningsprosjekt synes å være et problem, ikke minst når vurderingene ikke nødvendigvis er sammenfallende. Ulike syn på tilnærmet samme spørsmål, kan skyldes at instansene er opprettet med forskjellig formål. Det vil si at de skal ivareta forskjellige hensyn og at de forholder seg til ulike regelverk, og da gjerne regelverk som har andre primærformål enn å fremme god forskning. At de ulike instansene forholder seg til regelsett som heller ikke er harmonisert, forsterker problemet med overlapping.

Det er vanligvis unødvendig at flere instanser vurderer samme sider av prosjektet. Flere instanser, oppgavefordeling og spesialisering kan imidlertid også være et nødvendig gode. Det at spesialister på ulike områder er plassert $\mathrm{i}$ hver sine organer, har den fordel at saker som har tilknytning til ett område kan behandles raskt og innsiktsfullt. Men mange forskningsprosjekter har ofte tilknytning til flere områder. Da medfører spesialiseringen at det ofte må innhentes uttalelser fra en rekke organer, slik at forskningen forsinkes og kompliseres (3). For eksempel må det kunne legges til grunn at Datatilsynet har særlig kjennskap og oversikt over personvern- og personopplysningsretten, mens Legemiddelverket har særlige kunnskaper om legemidler. Slik spesialkunnskap kan generalister ha problemer med å opparbeide seg. Kjell Ottar Heggestad fremhever i sin hovedfagsoppgave om REK-VEST at komiteenes grunnleggende problem er "at dei interessene som står bak forsøka, leverer premissar og konklusjon for ei risikovurdering som komiteen ikkje har ressursar til å etterprøve" (22). Av den grunn hevder Heggestad at det "ser ut som komiteen viser meir respekt for den sosiale og psykologiske autonomien til forsøkspersonane enn for den fysiske autonomien. Dette er eit paradoks. Sakene frå komiteen viser at det ofte er mindre kontroversielt å utføre invasive eksperiment som kirurgi, prøvetaking og medisinering enn det er å ta munnleg eller skriftleg kontakt med folk om emne som vedgår deira liv" (22). Finland har til sammenligning opprettet spesialiserte etikkomiteer.

Et fragmentert og utilgjengelig, og dermed uklart regelverk, gjør det i seg selv vanskelig å føre effektiv kontroll. Det forhindrer forutsigbarhet, og øker faren for vilkårlighet når instansene skal treffe avgjørelser og komme med råd.

Det er derfor behov for forenkling og harmonisering både av selve regelverket (atferdsnormene) og kontroll- og tilsynssystemet. Effektivisering uten at det går ut over forsøkspersoners eller forskeres rettssikkerhet, må være et mål. Det betyr ikke nødvendigvis mindre kontroll, men mer effektiv kontroll. Det må bli enklere å forske. Forenklingen skal ikke gå utover kvaliteten. Tvert imot fremmer god og effektiv kontroll god forskning. Blant annet kan forskningsprosjektet forbedres gjennom en aktiv dialog med en kompetent instans. Det synes å være en av årsakene til at mange forskere er positive til behandlingen i de regionale etikkomiteene. Blir kontrollen bedre og mer effektiv, er det dessuten sannsynlig at den blir bedre kjent, bedre respektert og mer brukt. Dermed forhindres også dårlig forskning i større grad.

Vi ønsker å takke førsteamanuensis dr. juris Henriette Sinding Aasen for nyttige innspill.

\section{REFERANSER}

1. Nylennautvalget: www.forskningsregulering.dep.no.

2. Aasen HS. Pasientens rett til selvbestemmelse ved medisinsk behandling. Bergen: Fagbokforlaget, 2000: kapittel 11.

3. Eckhoff T, Smith E. Forvaltningsrett. 7. utg. Oslo: Universitetsforlaget, 2003.

4. Vogelsang TM. Gerhard Henrik Armauer Hansen. Oslo: Gyldendal forlag, 1968.

5. Blom K. Legeetikken og loven. Lov og Rett 1973: 360-368 
6. Annas GJ, Grodin MA, red. The Nazi Doctors and the Nuremberg Code, Human Rights in Human Experimentation. New York: Oxford University Press, 1992.

7. Møse E. Menneskerettigheter. Oslo: Cappelen Akademisk Forlag, 2002.

8. Ruyter K. Medisinske forskningsetikk 50 år etter Nürnberg. Tidsskr Nor Lageforen 1997; 117 (30): 4383-91.

9. The European Council: Convention for the Protection of Human Rights and Dignity of the Human Being with Regard to the Application of Biology and Medicine, vedtatt 4.4.1997, i kraft 1.12.1999.

10. Direktiv 2001/20/EF om klinisk forsøk av legemidler.

11. Forskrift om klinisk utprøving av legemidler av 23. september 2003.

12. Bernt JF, Rasmussen Ø. Frihagens Forvaltningsrett, bind I. Bergen: Fagbokforlaget, 2003.

13. Helsedepartementet: odin.dep.no/hd/norsk/index-b-n-a.html.

14. Sosial- og helsedirektoratet: www.shdir.no.

15. Berg BO. Rådet for taushetsplikt og forskning. Arkivmagasinet 2/99: 23-26.

16. Bioteknologinemnda: www.bion.no.

17. Statens legemiddelverk: www.legemiddelverket.no.

18. Statens helsetilsyn: www.helsetilsynet.no.

19. Datatilsynet: www.datatilsynet.no.

20. Personvernnemnda: www.personvernnemnda.no.

21. Andenæs J. Statsforfatningen i Norge. 9. utg. ved Fliflet A. Oslo: Universitetsforlaget, 2004

22. Heggestad KO. Risikokultur og eksperiment på menneske; Ei analyse av praksis i Den regionale komite for medisinsk forskningsetikk, Helseregion Vest. Hovedfagsoppgave. Bergen: Universitetet i Bergen, 2003.

23. Den nasjonale komité for medisinsk forskningsetikk (NEM): www.etikkom.no.

24. International Committee of Medical Journal Editors: Uniform Requirements for Manuscripts Submitted to Biomedical Journals: Writing and Editing for Biomedical Publication: www.icmje.org.

25. Norsk Samfunnsvitenskapelig Datatjeneste (NSD): www.nsd.uib.no.

26. Collins R, Doll R, Peto R. Ethics of clinical trials. I: Williams CJ, red. Introducing new treatments for cancer: practical, ethical and legal problems. Chichester: John Wiley, 1992.

27. Glasziou P, Chalmers I. Ethics review roulette: what can we learn? BMJ 2004; 328: 121-122. 